\title{
Co(II) Complex of Mefloquine Hydrochloride: Synthesis, Antimicrobial Potential, Antimalaria and Toxicological Activities
}

\author{
ADEDIJI J. FEMI ${ }^{*}$ AND OBALEYE J. AYOOLA ${ }^{2}$ \\ ${ }^{1}$ Department of Chemistry, Federal University of Agriculture Abeokuta, P.M.B. 2240, \\ Abeokuta, Ogun State, Nigeria \\ ${ }^{2}$ Department of Chemistry, University of Ilorin, P.M.B. 1515, Ilorin Kwara State \\ dijijohnson@yahoo.com
}

Received 4 April 2011; Accepted 2 June 2011

\begin{abstract}
Transition metal complex of Co(II) with Mefloquine hydrochloride (antimalaria drug) was synthesized using template method. Chemical analysis including conductivity measurements and spectroscopic studies were used to propose the geometry and mode of binding of the ligand to metal ion. From analytical data, the stoichiometry of the complex has been found to be $1: 1$. Infrared spectral data also suggest that the ligand (mefloquine hydrochloride) behaves as a tridentate ligand with N:N:O donor sequence towards the metal ion. The complex generally showed octahedral coordinate geometry. Conductivity measurement of $10^{-2} \mathrm{~mol} \mathrm{dm}^{-3}$ methanol solution of the complex indicated non-electrolytic nature of metal complex. It also revealed that the ligand anions were covalently bonded to the complex. In-vivo evaluation of antimicrobial studies of the metal complex showed greater activities when compared to the free mefloquine. The complex was screened against malarial parasites (Plasmodium yoelii nigeriensis): It was evident from the results obtained that $\operatorname{Co}(\mathrm{II})$ mefloquine has highest clearance of about $80 \%$ parasitaemia reduction compared to the free mefloquine. The ligand and metal complex were screened for their toxicological activities at the dose of $0.60 \mathrm{mg} / \mathrm{Kg}$ body weight twice daily for seven days on the alkaline phosphatase (ALP), alanine aminotranferase (ALT), and aspartate aminotransferase (AST) activities of rat serum, liver and kidney. Overall, it was revealed that both mefloquine and its metal complex do not showed toxicity particularly on the liver and kidney.
\end{abstract}

Key words: Transition metal, antimicrobial, antimalaria activity, toxicological studies.

\section{Introduction}

Complexation chemistry is quite simply the chemistry of coordination compounds containing a central atom or ion to which are attached molecules or ions whose number 
usually exceeds the number corresponding to the oxidation number or valence of the central atom or ion. They are of great theoretical importance and they are also of great practical utility as well ${ }^{1}$.

Over the past three decades, intensive efforts have been made to design novel compounds to confront new strains of resistance micro-organisms. The ongoing intense search for novel and innovative drug delivery systems is predominantly a consequence of the well established fact that the convectional dosage forms are not sufficiently effective in conveying the drug compound to its site of action and this have necessitated the needs to search for more potent drugs. The recognition of the potential employment of metal complexes and chelates in therapeutic application provides useful outlet for basic research in transition metal chemistry ${ }^{2,3,4,5}$.

Mefloquine Hydrochloride (Ligand employed in this study) is ( \pm )-erythro- $\alpha-(2-$ piperidyl)-2,8-bis(trifluoromethyl)-4-quinoline methanol, and it is known for antimalaria activity. The choice of quinoline moiety was as a result of the success with the case of chloroquine. Mefloquine was the only candidate drug that came off successfully during Vietnam War. Its total synthesis was first reported by Ohnmacht et al. ${ }^{6 .}$ More than 10,000 synthesized compounds, most of which were based on the quinoline moiety, were screened for antimalaria activity during the Vietnam War at the Walter Reed Army Institute (WRAI) in U.S.A ${ }^{7}$. Mefloquine is a white or slightly yellow, crystalline powder, very soluble in water, freely soluble in methanol and alcohol. It melts at about $260{ }^{\circ} \mathrm{C}$ with decomposition. It shows polymorphism. Since the ligand (mefloquine) consists of potential binding sites such as oxygen and two nitrogen atoms, this work set out to study the coordination tendencies, characterization after complexing with metal and the biological activities.

\section{Experimental}

\section{Material}

Metal salt, Cobalt (II) chloride hexahydrate used for the Complexation was obtained from British Drug Houses chemical limited, Poole, England and was used as supplied. The ligand (mefloquine hydrochloride) was obtained from SWISS pharmaceuticals Company Lagos, Nigeria. ALP, ALT, and AST assay kits were obtained from Randox Laboratories Limited, Antrim, United Kingdom. Isolates of Escherichia coli, Klebsiella pneumonia and staphylococcus aureus were obtained from the Department of Microbiology, University of Ilorin, Nigeria. Albino rats (Wistar strain) were obtained from the Department of Biochemistry, University of Ilorin, Ilorin, Nigeria. Plasmodium yoelii nigeriensis used in this study were obtained Through University of Ibadan Teaching Hospital. Swiss mice, obtained from the Department of Biological sciences, University of Ilorin, Nigeria. This study was carried out in the Department of Chemical Sciences Laboratory, Ajayi Crowther University, Oyo. Nigeria.

Infra-red spectra of the ligand and complex were recorded in $\mathrm{KBr}$ disc in the range $4000-600 \mathrm{~cm}^{-1}$ on PUC Scientific model 500 FTIR Spectrometer. Electronic spectra were done on Aquamate Spectrophotometer Model V4.60. The metal estimation was done using an Alpha4 Atomic Absorption Spectrophotometer with PM 8251 simple-pen recorder. 
Conductivity measurements were carried out using WTW Conductometer Bridge. Thin layer Chromatography was carried out using TLC plate coated with silica gel.

\section{Synthesis of the Metal Complex}

The complex was prepared based on previous reported procedures with slight modifications ${ }^{1,4} .0 .01 \mathrm{~mol}$ of ethanolic solutions of Cobalt(II) chloride $\left(\mathrm{CoCl}_{2} \cdot 6 \mathrm{H}_{2} \mathrm{O}\right)$ were prepared in a round bottomed flask. $0.01 \mathrm{~mol}(4.148 \mathrm{~g})$ of mefloquine hydrochloride was dissolved in 20 $\mathrm{cm}^{3}$ ethanol and added to the solution of the metal salt in $10 \mathrm{~cm}^{3}$ ethanol in a roundbottomed flask fitted with a condenser and refluxed with constant stirring for $2 \mathrm{~h}$. The chelate were separated out after leaving it for four days. The metal chelates thus separated were filtered and washed with methanol and then with distilled water to remove unreacted ligand and metal. Finally the solid complex was dried in a dessicator. 10\% methanolic ammonia (buffer) solution was used to maintain the $\mathrm{pH}$ of the reacting solution of metal salt and ligand under reflux.

\section{Antimicrobial Screening of the Ligand and Metal Complex}

The stimulatory or inhibitory activity of the ligand and the metal complex synthesized were determined according to the procedure previously reported by Obaleye and Famurewa ${ }^{8}$ as modified by Mohamed and Abdel-Wahab ${ }^{9}$. The bacteria species used for this test include clinical sample of Escherichia coli, Staphylococcus aureus and Klebsiella pneumonia. The antibacterial activities of the compounds were estimated on the basis of the size of the inhibition zone formed around the wells on sensitivity media. Antifungal activity of each compound was determined using culture of three fungi species; they are Aspergillus niger, Aspergillus flavus and Rhizopus species. They were cultured on potato dextrose agar. The plates were incubated aerobically at $28 \pm 2^{\circ} \mathrm{C}$ for $96 \mathrm{~h}$.

\section{Treatment of Animals}

Male albino rats (Wistar strain), weighing between 160 - $180 \mathrm{~g}$ were obtained from the Department of Biochemistry, University of Ilorin, Ilorin and housed in the animal house of the Department of Chemical Sciences, Ajayi Crowther University, Oyo, Nigeria for acclimatization. They were kept in wire meshed cages and fed with commercial rat chow (Bendel Feeds Nigeria Ltd) and water ad libitum.

Eighteen rats were divided into three groups of 6 rats per group. The first group was used as control and received distilled water. The second group of rats was treated with free ligand (mefloquine), while the third group was treated with metal complex $\left(\mathrm{Co}(\mathrm{Mef}) \mathrm{Cl}_{2}\right)$. The distilled water, ligand and solution of metal complex were administered orally to the rats of various groups two times daily, morning and evening for seven days at the dose of $0.60 \mathrm{mg} / \mathrm{Kg}$ body weight. The animals were sacrificed $24 \mathrm{~h}$ after the last treatment.

\section{Preparation of Serum and Tissue Homogenate}

The method described by Yakubu et al. ${ }^{10}$ was used to prepare the serum. The rats were sacrificed by stunning. Blood samples were collected by cardiac punctures into clean, dry centrifuge tubes after which they were left for $10 \mathrm{~min}$ at room temperature. The tubes were 
then centrifuged for $10 \mathrm{~min}$ at $3000 \mathrm{xg}$ in an MSC (Essex, UK) bench centrifuge. The clear supernatant (serum) was aspirated using a Pasteur pipette into clean, dry sample bottles and then frozen overnight before use. The liver and kidney excised from rat, blotted of blood stains were rinsed in $1.15 \% \mathrm{KCl}$ and homogenized in 4 volumes of ice-cold $0.01 \mathrm{~mol} \mathrm{dm}^{-3}$ potassium phosphate buffer ( $\mathrm{pH} 7.4)$. The homogenates were centrifuged at $12,500 \mathrm{x} \mathrm{g}$ for $15 \mathrm{~min}$ at $4{ }^{\circ} \mathrm{C}$ and the supernatants, termed the post-mitochondrial fractions (PMF) were aliquoted and used for enzyme assays.

\section{Determination of Serum and Tissue AST, ALT, and ALP Activities}

Serum and tissues AST, ALT and ALP activities were determined using Randox diagnostic kits. Determination of AST and ALT activities were based on the principle described by Reitman and Frankel (1957). ALP activity determination was based on the method of Wright et al. (1972). The yellow coloured p-nitro phenol formed was monitored at $405 \mathrm{~nm}$. Protein determination of serum and all fractions was estimated by the method of Lowry et $a l .{ }^{13}$ as modified by Yakubu et al. and Malomo et al ${ }^{10,21}$ using bovine serum albumin as standard.

\section{Statistical Analysis}

The data were analyzed using one way ANOVA followed by Duncan multivariable posthoc test for comparison between control and treated rats in all groups. P values less than 0.05 were considered statistically significant.

\section{Antimalarial Activities}

The method used by Obaleye et al, ${ }^{14}$ was employed with slight modifications.

Nine Swiss mice were divided into three groups with three rats per group. They were inoculated with $0.2 \mathrm{ml}$ of $1 \times 10^{6}$ parasitized erythrocytes suspended in buffered physiological saline ( $\mathrm{pH}$ 7.4). After 96hours of infection, the degree of parasitaemia was determined from Glemsa stained thin blood smears by examining 100 erythrocytes in 5 different fields. This was expressed as a percentage of cell parasitized ${ }^{14}$. On the same day, the drug was administered to the mice. A solution of ligand and metal complex was prepared with a concentration of $1 \mathrm{ppm}$ each. $0.4 \mathrm{ml}$ of the solutions was injected into the mice in each group, while only physiological saline solution was given to the control animals. The mice were left for another 4 days after which a blood smear was prepared to check the level of parasitaemia.

\section{Results and Discussion}

The metal chloride salt reacts with the ligand, $\mathrm{L}(\mathrm{L}=$ Mefloquine) forming a compound ([M(II) $\left.\left.\mathrm{LCl}_{2}\right]\right)$ using the proposed equation:

$$
\mathrm{MX}_{2}+\mathrm{L} \rightarrow \mathrm{ML} . \mathrm{X}_{2}
$$

Where $\mathrm{M}=\mathrm{Co}^{2+}$ metal salt $\mathrm{L}=$ mefloquine and $\mathrm{X}^{-}=$Chloride ion.

The complex synthesized was found to be a non-hygroscopic solid with a peach colour (Table1). The complex is very soluble in ethanol, methanol and distilled water. It has a 
sharp melting point, and no decomposition observed. The average percentage yield was $62.0 \%$. The retention factor $\left(\mathrm{R}_{\mathrm{f}}\right)$ values were calculated from the developed single spot for the complex indicating the purity of the compound ${ }^{9}$. The $\mathrm{R}_{\mathrm{f}}$ of the metal complex was found to be higher than the ligand. Comparing the conductivity of the ligand with that of the metal complex at a room temperature suggests that it is non-electrolytic in nature. The analytical data of the anti-malarial metal complex showed 1:1 stoichiometry.

The UV-spectra of the ligand and its metal complex have been interpreted in terms of charge transfer transitions from the metal to the anti-bonding orbital of the ligand and of the $\pi \rightarrow \pi^{*}$ transitions of the ligand ${ }^{15}$. The ultraviolet spectrum of the free mefloquine $\mathrm{HCl}$ shows two absorption bands at $272.0 \mathrm{~nm}$ and $207.0 \mathrm{~nm}$ (Table 2). These transitions involve energies of $36765 \mathrm{~cm}^{-1}$ and $48309 \mathrm{~cm}^{-1}$. The bands have been assigned to the $\mathrm{n} \rightarrow \pi^{*}$ and $\mathrm{n}$ $\rightarrow \sigma^{*}$ transition respectively. These bands undergo hypsochromic shifts in the metal complex due to Complexation. The infrared data (Table 3) showed the results of the most informative and indicative region. The assignments have been interpreted based on literature values obtained for similar structural compounds ${ }^{14}$.

The shifts observed in the absorption bands between mefloquine and its metal complex showed that there is coordination. Metal-Ligand bands were observed in the ranges of $610-950 \mathrm{~cm}^{-1}$ in the metal complex. The Co (II) complex shows a $\mu_{\text {eff }}$ value of 3.5 BM, which corresponds to high spin (octahedral) stereochemistry ${ }^{16}$.

Table 1. Some physical properties of mefloquine and its metal complex.

\begin{tabular}{|c|c|c|c|c|}
\hline Compounds & Melting point $\left({ }^{\circ} \mathrm{C}\right)$ & Colour & $\begin{array}{c}\% \\
\text { yield }\end{array}$ & $\begin{array}{c}\text { Conductivity } \\
\left(\Omega^{-1} \mathrm{~cm}^{-1} \mathrm{dm}^{-3}\right)\end{array}$ \\
\hline Mefloquine(Mef)Co(Mef)Cl $\mathrm{Cl}_{2}$ & $\begin{array}{c}259-260 \\
242\end{array}$ & $\begin{array}{c}\text { White } \\
\text { Peach }\end{array}$ & $\begin{array}{c}- \\
62.0\end{array}$ & $\begin{array}{c}- \\
1.287 \times 10^{-4}\end{array}$ \\
\hline
\end{tabular}

Table 2. Ultraviolet/Visible spectral assignment of mefloquine and its metal complex.

\begin{tabular}{|c|c|c|}
\hline Compound & $\begin{array}{c}\text { Wavelength } \\
(\mathrm{nm})\end{array}$ & $\begin{array}{c}\text { Wave number } \\
\left(\mathrm{cm}^{-1}\right)\end{array}$ \\
\hline \multirow{2}{*}{ Mefloquine(Mef) } & 272.00 & 36765 \\
& 207.00 & 48309 \\
\hline \multirow{2}{*}{$\mathrm{Co}(\mathrm{Mef}) \mathrm{Cl}_{2}$} & 317.0 & 31546 \\
& 284.0 & 35211 \\
& 222.0 & 45045 \\
& 207.0 & 48309 \\
\hline
\end{tabular}

Table 3. IR spectral assignment of mefloquine and its metal complex. 


\begin{tabular}{|c|c|c|}
\hline $\begin{array}{c}\text { Mefloquine } \\
\left(\mathrm{cm}^{-1}\right)\end{array}$ & $\begin{array}{l}\mathrm{Co}(\mathrm{Mef}) \mathrm{Cl}_{2} \\
\left(\mathrm{~cm}^{-1}\right)\end{array}$ & $\mathrm{v}(\mathrm{OH}), \mathrm{v}(\mathrm{N}-\mathrm{H})$ stretch \\
\hline $3447.4 \mathrm{w}, \mathrm{b}$ & $3376.8 \mathrm{~b}$ & $\mathrm{v}(\mathrm{C}-\mathrm{H})$ stretch of $\mathrm{CH}_{3}$ \\
\hline $2925.1 \mathrm{~s}, \mathrm{~b}$ & $2942.5 \mathrm{w}, \mathrm{b}$ & $\mathrm{v}(\mathrm{C}=\mathrm{N})$ \\
\hline $1586.2 \mathrm{~s}$ & $1590.0 \mathrm{~s}$ & $\mathrm{v}(\mathrm{C}-\mathrm{N})$ stretch \\
\hline $1380.9 \mathrm{~s}$ & $1355.2 \mathrm{~s}$ & \\
\hline
\end{tabular}

Table 4. Magnetic moment of the ligands and metal complexes.

\begin{tabular}{|l|c|c|c|c|}
\hline Compound & Empirical formula & $\begin{array}{c}\text { Formular } \\
\text { weight }\end{array}$ & $\begin{array}{c}\mu_{\text {eff }} \\
(\mathrm{BM})\end{array}$ & $\begin{array}{c}\% \text { Metal content } \\
\text { found } \\
\text { (calculated) }\end{array}$ \\
\hline Mefloquine & $\mathrm{C}_{17} \mathrm{H}_{16} \mathrm{~F}_{6} \mathrm{~N}_{2} \mathrm{O}$ & 414.80 & - & - \\
\hline $\mathrm{Co}(\mathrm{Mef}) \mathrm{Cl}_{2}$ & $\mathrm{Co}\left(\mathrm{C}_{17} \mathrm{H}_{16} \mathrm{~F}_{6} \mathrm{~N}_{2} \mathrm{O}\right) \mathrm{Cl}_{2}$ & 544.80 & 3.50 & $8.90(9.04)$ \\
\hline
\end{tabular}

Figs 1 and 2 show the results of antibacterial and antifungal activities of free mefloquine and the metal complex. The studies of the ligand and its metal complex gave the antimicrobial activity of the compounds. The Metal complex was found to be more active at higher $\left(1.0 \mathrm{~g} / \mathrm{dm}^{3}\right)$ concentration than its corresponding ligand. The synthesized complex was active against the three bacteria used, while they were found to be active against only two of the fungi used, Aspergillus niger and Aspergillus flavus. Reports have shown that $\mathrm{CoCl}_{2} \cdot 6 \mathrm{H}_{2} \mathrm{O}$ has no inhibitory activity on bacteria and fungi species ${ }^{14}$.

Figs 3 - 5 show the results of ALT, AST and ALP activities of the serum, kidney and liver of rat. There was a significant increase $(p<0.05)$ in serum ALT, AST and ALP activities of mefloquine and its metal complex treated rats compared with the control, with the mefloquine group higher than the metal complex. The data also indicate that there was a significant reduction $(\mathrm{p}<0.05)$ in the liver and kidney ALT, AST and ALP activities of mefloquine and its metal complex treated rats compared with the control, with the mefloquine group lower than the metal complex. The observed significant increase in the serum ALT, AST and ALP activities with a concomitant significant reduction in the same enzymes activities in the liver and kidney of rats administered with mefloquine and the metal complex may be as a result of stress imposed on the tissue by the drug, which may lead to loss of the enzyme molecule through leakage into extra-cellular fluid. ALP is a membrane-bound enzyme often used to assess the integrity of the plasma membrane and endoplasmic reticulum ${ }^{20}$. AST and ALT are enzymes associated with liver parenchymal cells. They are raised in acute liver damage. They are also present in red blood cells, heart cells, muscle tissue, pancreas and kidneys. When body tissue or an organ such as the heart or liver is diseased or damaged, additional AST and ALT are released into the bloodstream. 
Both ALT and AST levels are reliable indicators of liver damage. In short, increase in serum ALT and AST has been reported in conditions involving necrosis of hepatocytes ${ }^{18}$, myocardial cells, erythrocyte and skeletal muscle cells ${ }^{19}$. Alteration in serum/tissue levels of AST, ALT and ALP as recorded in these studies are indications of derangement in cellular activities and hence no toxicity in both metal complex group and the mefloquine group.

Fig 6 shows the antimalaria activities of the metal complex. Co (II) complex has the best clearance with $80 \%$ reduction in parasitaemia.

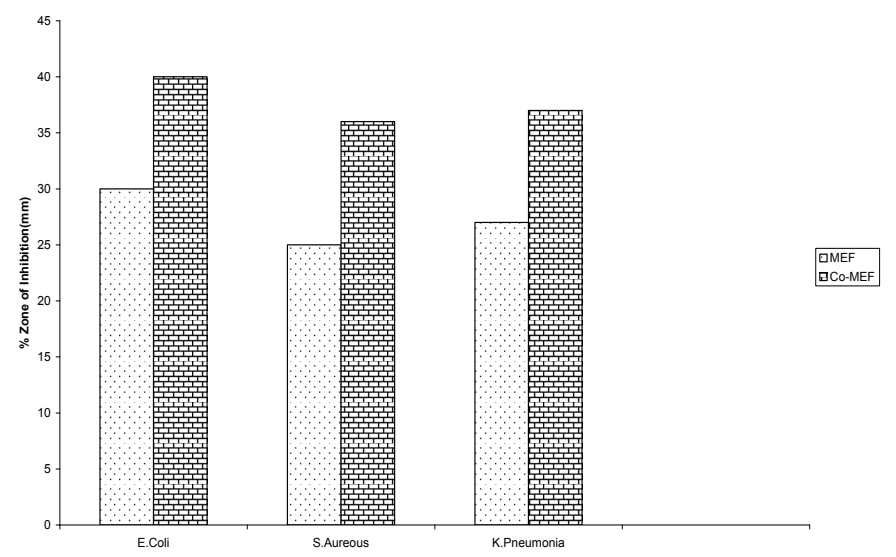

Figure 1. Inhibitory activity of the ligands and metal complexes against Escherichia coli; Staphylococcus aureus, and Klebsiella pneumonia.

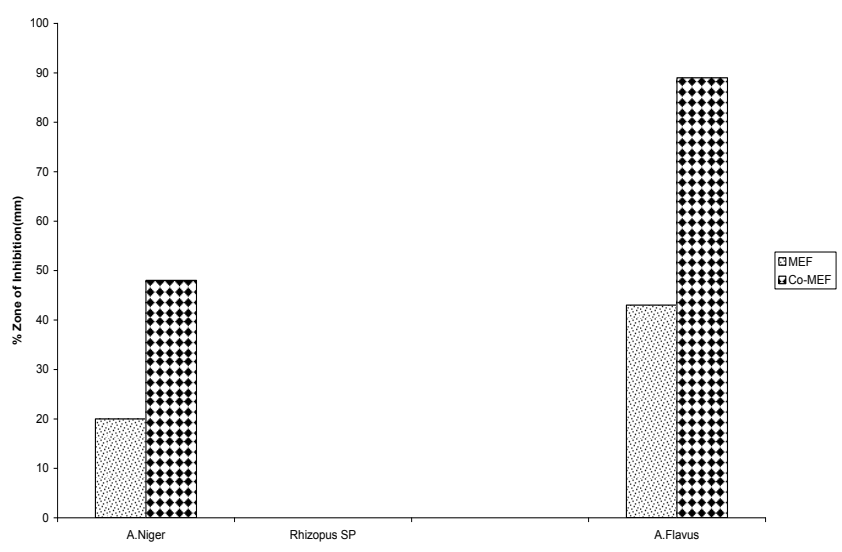

Figure 2. Inhibitory activity of the ligands and metal complexes against Aspergillus niger, Rhizopus species, and Aspergillus flavus. 


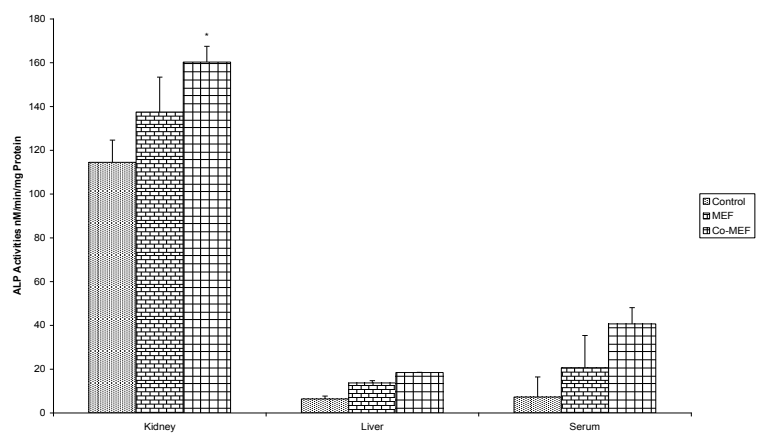

Figure 3. Effect of administration of ligands and metal complexes on the activities of alanine amino transferase (ALP) of rat serum, kidney and liver.

* Significantly different from the control $(\mathrm{p}<0.05)$.

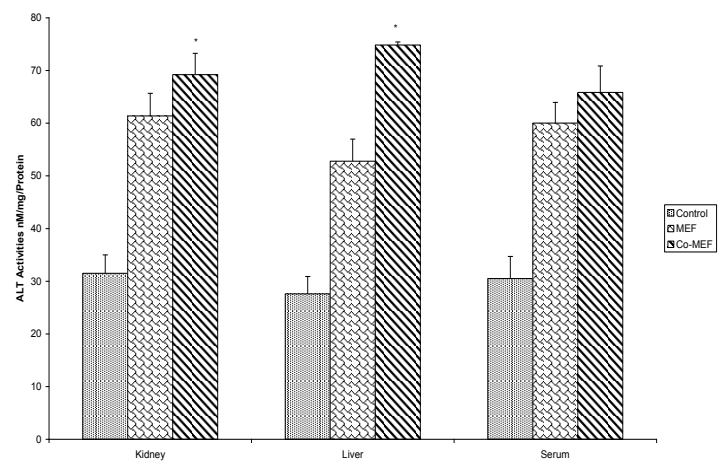

Figure 4. Effect of administration of ligands and metal complexes on the activities of aspartate amino transferase (ALT) of rat serum, kidney and liver.

* Significantly different from the control $(\mathrm{p}<0.05)$.

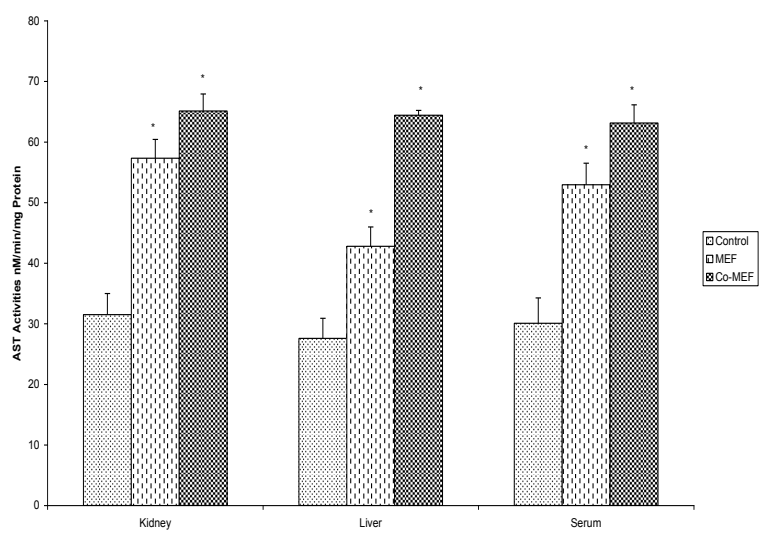

Figure 5. Effect of administration of ligands and metal complexes on the activities of alkaline phosphatase (AST) of rat serum, kidney and liver.

* Significantly different from the control $(\mathrm{p}<0.05)$. 


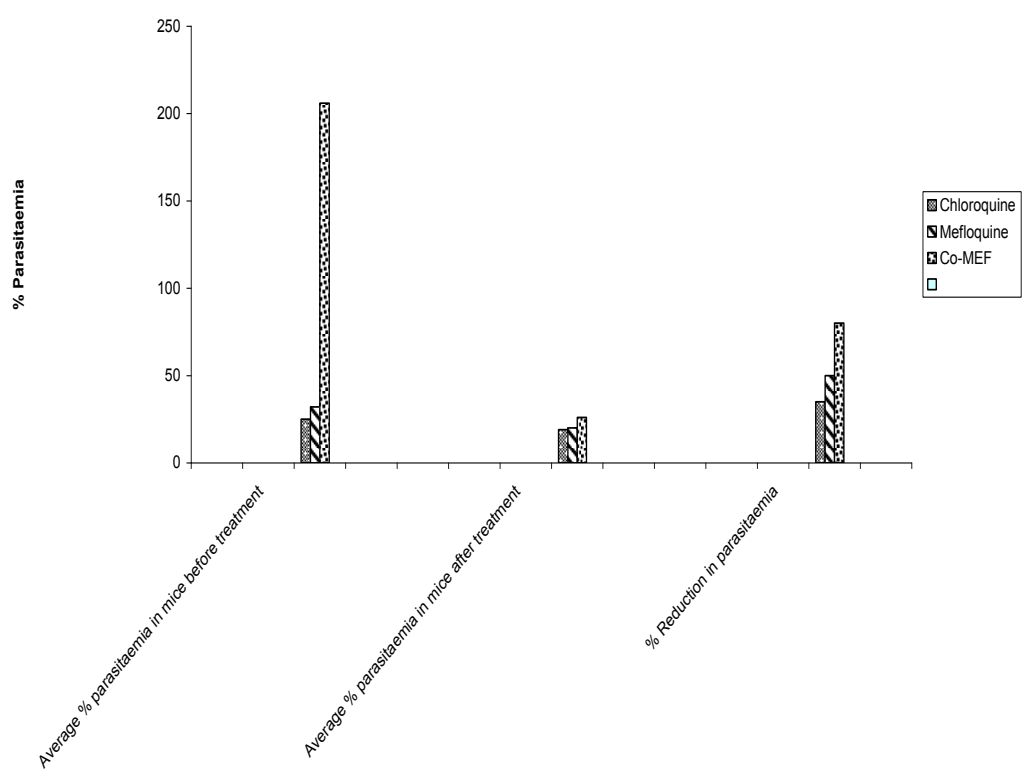

Figure 6. Percentage Parasitaemia Of Ligand and Metal Complex Using Mice infected with Plasmodium yoelii nigeriensis.

\section{Conclusion}

The results of the chemical and physical analysis from this study show that the ligand (mefloquine) employed in this work coordinated with Co (II). The metal complex possesses better physical properties than the parent compound. The toxicological studies revealed metal complex showed mild toxicity particularly on the liver and kidney. Antimalaria activities also revealed $80 \%$ clearance in parasitaemia reduction. Therefore it is evident that the metal complex would be a better therapeutic drug for treatment of malaria. This approach might be useful in Pharmacological research in solving the problem of drug resistance in malaria chemotherapy.

\section{Aknowledgement}

The authors appreciate the financial support of Science and Technology Education Post Basic (STEP B), University of Ilorin and Ajayi Crowther University, Oyo.

\section{References}

1. Nadira W, Singh HB. Inorg. Chim. Acta. 1987, 135:134-137.

2. Obaleye JA, Nde-aga JB, Balogun EA. Afr. J. Sci. 1997,1:10-12.

3. Ogunniran KO, Ajanaku KO, James OO, Ajani OO, Nwinyi CO, Allansela. Int. J. Phy. Sci. 2008, 3(8):177-182.

4. Adediji, J F, Olayinka ET, Adebayo MA, Babatunde O. Int. J. of physical sciences 2009, 4(9): 529-534.

5. Adediji J.F. Adebayo M.A.and Obaleye J.A : Asian journal of Applied Sciences.2011, 4(4): 392-402. DOI: 10.3923/ajaps.2011.392.402.

6. Ohnmacht C.J, Patel A.R, Lutz R.E. J. Med. Chem,1971, 14,926. 
7. WHO Drug Information (1987). Vol 1. No3, pp 127

8. Obaleye J.A, Famurewa O). Bios. Res. Comm. 1989, 1:87-93.

9. Mohamed G.G, Abdel-Wahab Z.H. Spectrochimica Acta. Part A: Molecular and Biomolecular Spectroscopy.2005, 9(61):2231-2238.

10. Yakubu MT, Akanji MA, Oladiji AT. Asia J. Androl. 2005,7:399-404.

11. Rietman S, Frankel S. Am. J. Chem. Path. 1957, 28:56-63.

12. Wright PJ, Plummer DT, Leathwood PT . Enzymologia 1972,42:317-327.

13. Lowry OH, Rosebrough NJ, Farr AL, Randall RJ. J. Biol. Chem. 1951, 193:265-275.

14. Obaleye J.A, Balogun E.A, Adeyemi OG. Biokemistri. 1999, 9(1):23-27.

15. Williams HD, Flemming I (1980). Methods in Organic Chemistry, 4th ed. McGraw-Hill Book Ltd, London.

16. Kamruddin SK, Roy A. Indian J. Chem. 2001, 40a(2):211-212.

17. Akanji MA, Ngaha EO. J. Pharm. Toxicol.1989, 64:272-275.

18. Macfarlane I, Bomford A, Sherwood R.A (2000). Laboratory Medicine. ACB Ventures Publications, London.

19. Halworth M, Capps N (1993). Therapeutic Drugs Monitoring and Clinical Biochemistry, ACB Ventures Publications, London.

20. Akanji, M.A, Olagoke O.A, Oloyede O.B. Toxicol. 1993, 81:173-179.

21. Malomo S.O, Ale O.O, Adedoyin A.M. Biosci. Res. Commun. 1993, 5:53-55. 


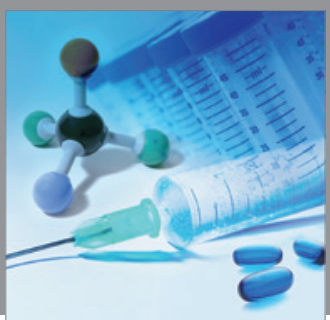

International Journal of

Medicinal Chemistry

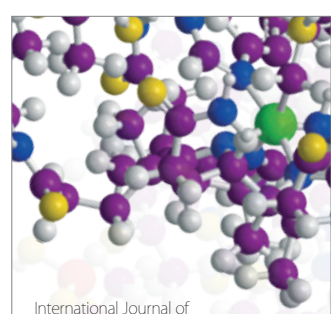

Carbohydrate Chemistry

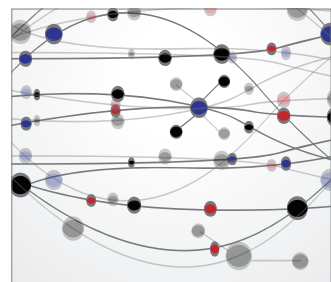

The Scientific World Journal
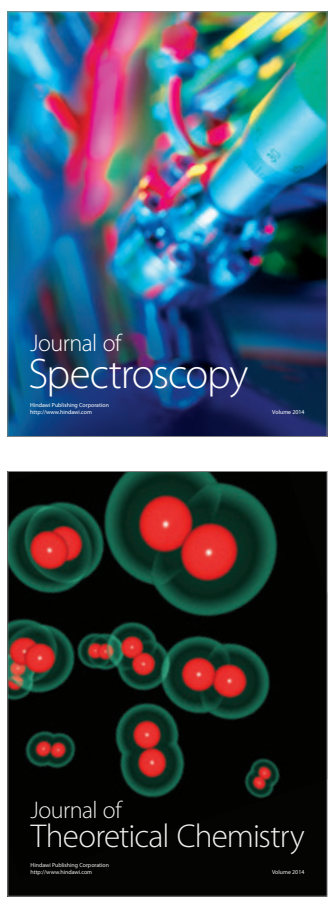
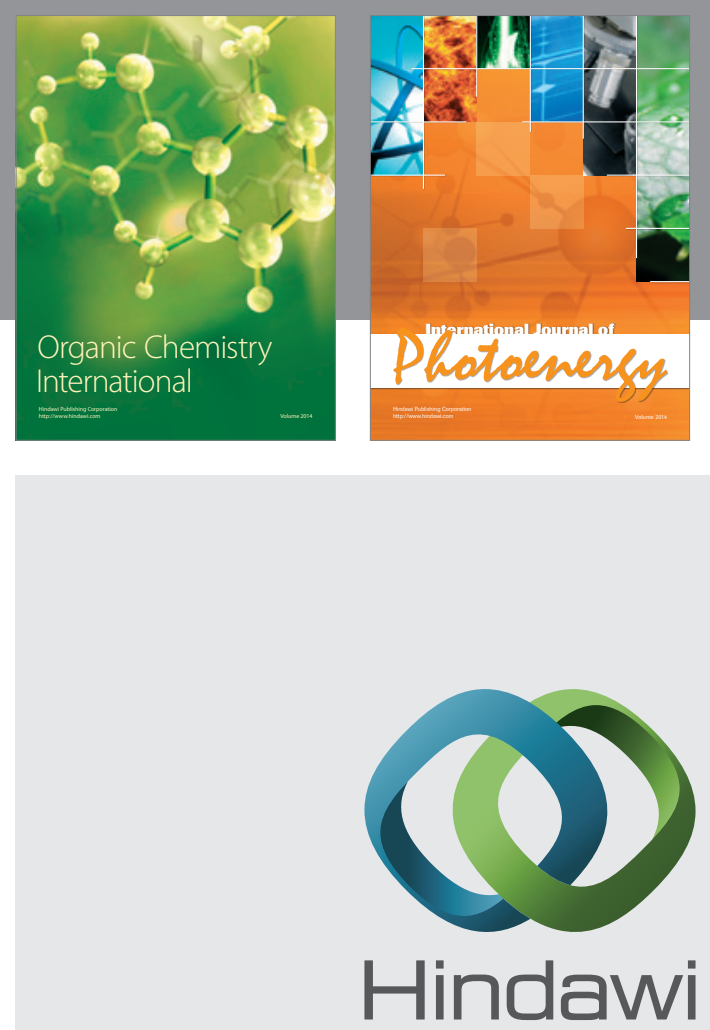

Submit your manuscripts at

http://www.hindawi.com
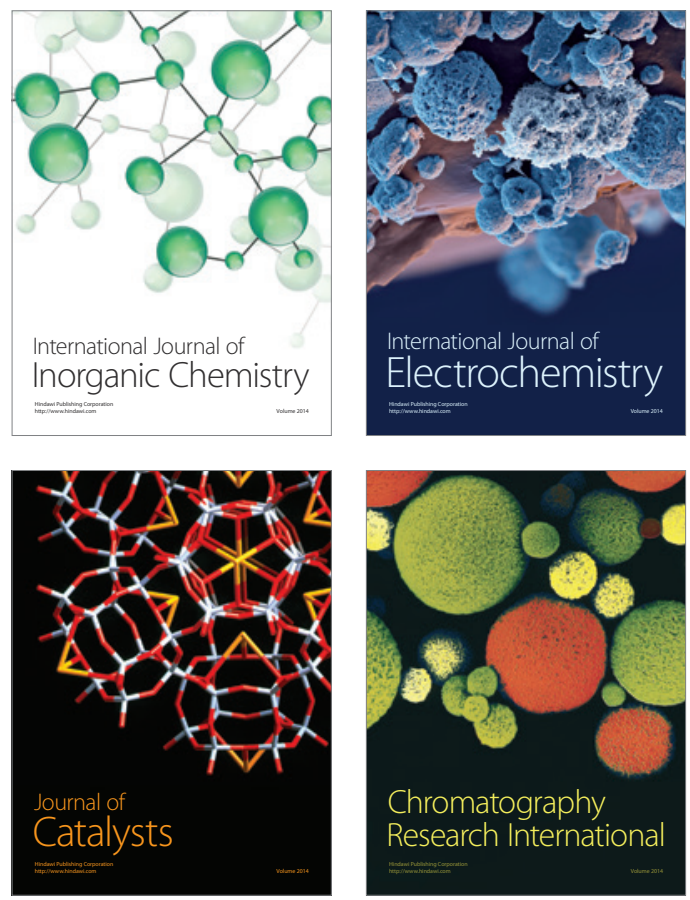
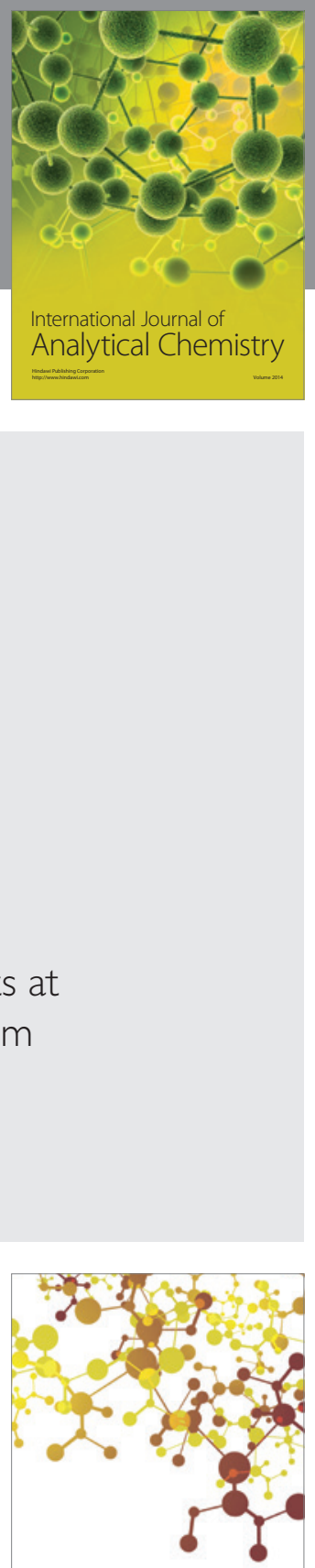

Journal of

Applied Chemistry
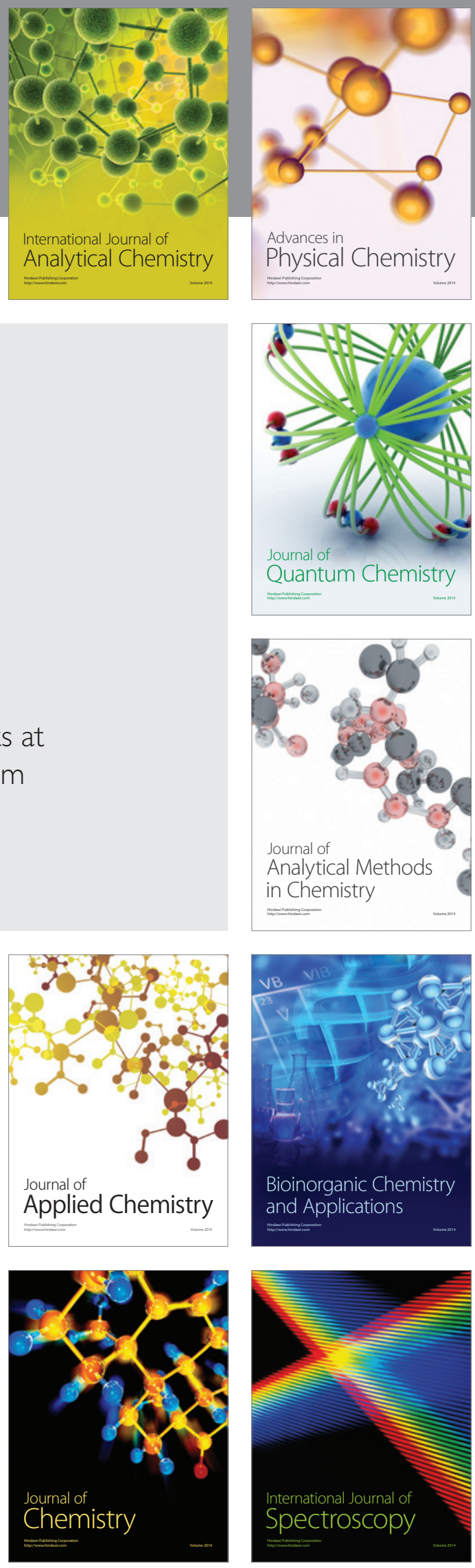